\title{
Effects of tamoxifen and ethynylestradiol cotreatment on uterine gene expression in immature, ovariectomized mice
}

\author{
Cora J Fong ${ }^{1,2}$, Lyle D Burgoon ${ }^{1,2}$, Kurt J Williams ${ }^{3}$, A Daniel Jones ${ }^{1}$, Agnes L Forgacs ${ }^{1}$ \\ and Timothy R Zacharewski ${ }^{1,2}$ \\ ${ }^{1}$ Department of Biochemistry and Molecular Biology, Michigan State University, 501 Biochemistry Building, Wilson Road, East Lansing, Michigan 48824-1319, USA \\ ${ }^{2}$ Center for Integrative Toxicology, National Food Safety and Toxicology Center and ${ }^{3}$ Department of Pathobiology and Diagnostic Investigation, Michigan State University, \\ East Lansing, Michigan 48824, USA \\ (Correspondence should be addressed to T R Zacharewski at Department of Biochemistry and Molecular Biology, Michigan State University; Email: tzachare@ @msu.edu)
}

\begin{abstract}
Tamoxifen (TAM), the primary treatment for estrogen receptor (ER)-positive breast cancer, has been associated with an increased incidence of endometrial cancer in postmenopausal, but not premenopausal women. TAM elicits a partial ER-mediated uterotrophic response in immature rodents when compared with ethynylestradiol (EE), a potent ER agonist. However, cotreatment with $1000 \mu \mathrm{g} / \mathrm{kg}$ TAM antagonizes the uterotrophic effect induced by $30 \mu \mathrm{g} / \mathrm{kg}$ EE. To further investigate the anti-uterotrophic activity of TAM, immature, ovariectomized C57BL/6 mice were treated with a single oral dose of EE, TAM, EE + TAM, or vehicle, and harvested at 2, 4, 8, 12, 18, and $24 \mathrm{~h}$ or after three daily treatments at $72 \mathrm{~h}$. Significant increases in uterine wet weight (UWW) were observed at $18 \mathrm{~h}$ for EE, TAM, and the mixture. However, mixture induction of UWW was significantly lower when compared with EE-induced uterotrophy at $72 \mathrm{~h}$. This inhibitory effect is also reflected in decreases in luminal circumference, yet EE-induced luminal epithelial cell height was unaffected by cotreatment with TAM. Gene expression analysis using a $2 \times 2$ factorial cDNA microarray study design identified 2518 differentially expressed genes following EE treatment alone. However, only 290 EE-elicited gene expression changes were affected by TAM cotreatment, in a manner consistent with the anti-estrogenic response. These data suggest that TAM antagonism of EE-induced UWW increase involves the selective inhibition of EE-induced genes.
\end{abstract}

Journal of Molecular Endocrinology (2010) 45, 161-173

\section{Introduction}

Tamoxifen (TAM) is an adjuvant and prophylactic therapy prescribed for estrogen receptor $\alpha(\mathrm{ER} \alpha$, listed as ESR1 in the HGNC database)-positive breast cancers. Adjuvant therapy suppresses breast cancer recurrence by $50 \%$ and prophylatically reduces incidence in highrisk populations (Lewis \& Jordan 2005). TAM and its active metabolites, 4-hydroxytamoxifen (4OH-TAM), $\mathrm{N}$-desmethyltamoxifen (DMT), and 4-hydroxy-DMT (endoxifene), are thought to act by competing with potent agonists for binding to the ER and inhibiting their proliferative effects (Jordan 1993, Massarweh et al. 2008).

Despite its high therapeutic index, TAM has been associated with a twofold risk increase in endometrial cancer (Houssami et al. 2006) and can stimulate endometrial growth and hyperplasia in postmenopausal women (Kedar et al. 1994, Vosse et al. 2002). TAM induces uterotrophy in immature and ovariectomized rodents and elicits a gene expression profile similar to estrogen in uterine tissue, albeit with lower efficacy (Hodges et al. 2003, Frasor et al. 2004, Fong et al. 2007, Kwekel et al. 2009). Despite TAM exhibiting partial ER-agonist activity in the uterus, there are significant differences between TAM and full agonists.
Comparisons between TAM and estrogen have shown that TAM causes a high induction of adenomyosis characterized by disordered location of endometrial glands in the myometrium of neonatal mice (Parrott et al. 2001), not observed with estrogen. TAM lacks the stimulation of water imbibition that is clearly induced in the presence of $17 \beta$-estradiol $\left(\mathrm{E}_{2}\right)$ and 17a-ethynylestradiol (EE; Reel et al. 1996). Moreover, numerous studies report unique gene expression changes elicited by TAM (Pole et al. 2005, Fong et al. 2007, Kwekel et al. 2009).

Although TAM and estrogen independently elicit a uterotrophic response, cotreatment at appropriate ratios results in an antagonistic effect. For example, TAM significantly repressed uterine weight after 28 days in intact adult mice (Sourla et al. 1997). In addition, it antagonizes $\mathrm{E}_{2}$-induced uterotrophy (Robertson et al. 1982), as well as $\mathrm{E}_{2}$ induction of progesterone receptor (Castellano-Diaz et al. 1989) and Fos (Kirkland et al. 1993) expression. Reporter gene (McInerney \& Katzenellenbogen 1996) and peroxidase activity (Robertson et al. 1982) assays have also exhibited similar antagonistic effects.

ER conformational changes after ligand binding affect its subsequent activities. The ligand-binding

DOI: 10.1677/JME-09-0158 Online version via http://www.endocrinology-journals.org 
domain occupied with $\mathrm{E}_{2}$ takes on a ligand-trapping conformation involving helix-12. In contrast, selective antagonists, such as raloxifene, position helix-12 in an orientation where the C-terminal domain of the ER interferes with subsequent transactivation (Brzozowski et al. 1997, Pike et al. 1999). Ligand-induced conformations have been implicated in coactivator protein recruitment. For example, GRIP1 is recruited to $\mathrm{E}_{2}$-bound ER, but not 4OH-TAM-bound receptor (Shiau et al. 1998). Moreover, coactivator recruitment may influence the activated receptors that bind to specific promoter sequences. This was demonstrated through DNA footprinting to show that high-mobility group B coactivator proteins enhance ER binding to estrogen response elements (EREs) (Das et al. 2004). Collectively, these studies indicate that ligand-induced topology can influence gene-specific transcriptional activation (reviewed in Edwards (2000)), and suggest that TAM may elicit its tissue-specific agonist and antagonist activities through a unique ER complex conformation. However, elucidating the influence of ligand structure on receptor conformation and transcriptional activity warrants further investigation.

This report extends our previous studies examining ER-mediated changes in uterine gene expression elicited by EE, a full ER agonist with enhanced oral bioavailability (Bolt 1979), and TAM (Fertuck et al. 2003, Kwekel et al. 2005, Fong et al. 2007), by examining their effects after cotreatment. A temporal $2 \times 2$ factorial microarray hybridization design (Fig. 1A; Yang \& Speed 2002) was used to comprehensively examine differential gene expression associated with the antagonism of EE-induced uterine wet weight (UWW) by TAM cotreatment, with complementary histopathology. Interestingly, global repression of gene expression changes was not observed in only a select subset of EE-induced genes affected by cotreatment. Moreover, the responses were associated with cell growth and proliferation pathways, consistent with the anti-uterotrophic effect.

\section{Materials and methods}

\section{Animal husbandry and treatment}

Female C57BL/6 mice, ovariectomized by the vendor on postnatal day (PND) 20, were obtained from Charles River Laboratories (Raleigh, NC, USA) on PND 25. Animals $(n=5)$ were housed in polycarbonate cages bedded with cellulose fiber chips (Aspen Chip Laboratory Bedding, Northeastern Products, Warrensberg, NY, USA) in a $23{ }^{\circ} \mathrm{C}$ environment with $30-40 \%$ humidity and a $12 \mathrm{~h}$ light:12 h darkness cycle $(0700-1900 \mathrm{~h})$. Animals had access to deionized water and Harlan Teklad 22/5 Rodent Diet 8640 (Madison, WI, USA) and

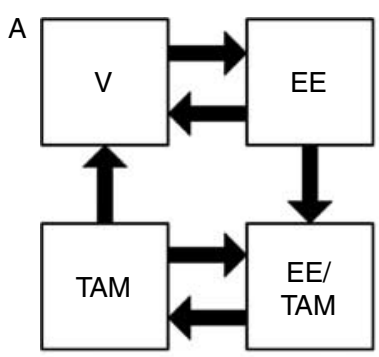

B Treatment schedule

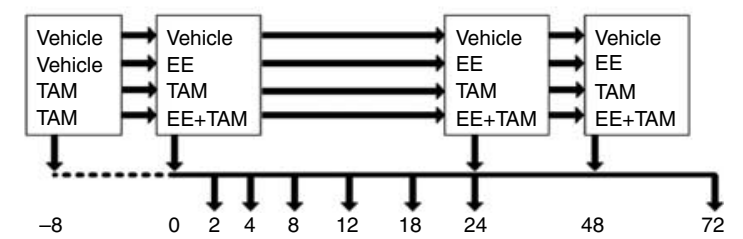

Killing schedule

Time (h)

Figure 1 Study design: (A) differential gene expression changes between all treatments were examined using a $2 \times 2$ factorial hybridization design to minimize the number of arrays required per biological replicate. Each arrow represents an array with Cy3 as the head and Cy5 as the tail. Microarray analysis was completed in triplicate for $2,4,12,24$, and $72 \mathrm{~h}$ time points for a total of 90 arrays. (B) Dosing and killing schedule for the study. Mice $(n=5)$ were treated with vehicle, $30 \mu \mathrm{g} / \mathrm{kg} \mathrm{EE}, 1000 \mu \mathrm{g} / \mathrm{kg}$ TAM, or

$30 \mu \mathrm{g} / \mathrm{kg}$ plus $1000 \mu \mathrm{g} / \mathrm{kg}$ TAM (MIX). Animals were killed at 2, 4, $8,12,18$, or $24 \mathrm{~h}$ after a single oral gavage or at $72 \mathrm{~h}$ with three daily doses at 0,24 , and $48 \mathrm{~h}$. TAM was dosed $8 \mathrm{~h}$ before EE to compensate for the delayed TAM-elicited responses associated with metabolism and distribution to facilitate equal competition for estrogen receptor availability.

were allowed to feed ad libitum and acclimatized for 4 days before treatment. TAM (Sigma) and EE (Sigma) were dissolved in sesame oil (Sigma) to the desired concentrations. To account for the delayed gene expression responses (Fong et al. 2007), animals ( $n=5$ per group) were primed at $-8 \mathrm{~h}$ with $1000 \mu \mathrm{g} / \mathrm{kg}$ TAM (TAM and mixture (MIX) groups) or sesame oil (vehicle and EE groups; Fig. 1B). At $0 \mathrm{~h}$, animals were dosed with $30 \mu \mathrm{g} / \mathrm{kg}$ EE (EE and MIX groups) or sesame oil (TAM and vehicle groups). Four groups $(n=5)$ of mice were also treated with sesame oil, $30 \mu \mathrm{g} / \mathrm{kg}$ EE (Sigma), $1000 \mu \mathrm{g} / \mathrm{kg}$ TAM (Sigma), or $30 \mu \mathrm{g} / \mathrm{kg} \mathrm{EE}$ and $1000 \mu \mathrm{g} / \mathrm{kg}$ TAM (MIX) at 24 and $48 \mathrm{~h}$ to represent the $3 \times 24 \mathrm{~h}$ treatment group. Doses were prepared based on average animal weight. Animals were killed by cervical dislocation, and body weights were recorded. The uterus was transected at the border of the cervix, and stripped of extraneous connective tissue and fat. Whole uterine weights were recorded before (wet weight) and after blotting (blotted weight) with absorbent tissue. A 6-8 mm section of unblotted uterine horn was placed in $10 \%$ neutral-buffered formalin (NBF) for histology. The remainder was snap frozen in liquid nitrogen and stored at $-80^{\circ} \mathrm{C}$ for RNA extraction. Liver sections 
from the left lobe were snap frozen for LC/MS/MS analysis. All procedures were performed with the approval of the Michigan State University All-University Committee on Animal Use and Care.

\section{Histological processing, morphometric, and pathological analysis}

Samples in $10 \%$ NBF were allowed to fix for at least $24 \mathrm{~h}$ at room temperature, then placed into tissue cassettes, and stored in $30 \%$ ethanol holding solution at $4{ }^{\circ} \mathrm{C}$. Paraffin embedding, sectioning $(5 \mu \mathrm{m})$, mounting, and hematoxylin and eosin staining were completed by the Michigan State University Laboratory for Anatomical Histology and Molecular Sciences (East Lansing, MI, USA) using standard techniques. Assessments were evaluated according to standardized National Toxicology Program pathology codes.

Morphometric analysis was performed on midhorn uterine cross sections ( $n=5$ per treatment group) using Scion Image analysis software (Scion Corp., Frederick, MD, USA). Histological markers of uterotrophy, including luminal epithelial cell height (LECH), luminal circumference, and a number of endometrial glands, were quantified. Statistical analysis of morphometry data was assessed by Dunnett's or two-way ANOVA followed by Tukey's honestly significant difference (HSD) post hoc analysis to examine dose-dependent and temporal effects respectively (SAS version 9.1; SAS Institute Inc., Cary, NJ, USA).

\section{RNA isolation}

Briefly, $1.0 \mathrm{ml}$ Trizol (Invitrogen) was added to the frozen uterine tissue in a $2.0 \mathrm{ml}$ microfuge tube and homogenized in the presence of steel beads by a Mixer Mill 300 homogenizer (Retsch, Haan, Germany). Total RNA was isolated and extracted according to the manufacturer's protocol and resuspended in the RNA Storage Solution (Ambion, Austin, TX, USA). RNA samples were quantified spectrophotometrically $\left(\mathrm{A}_{260}\right)$ and assessed for quality by $\mathrm{A}_{260} / \mathrm{A}_{280}$ ratio as well as inspected using denaturing agarose gel electrophoresis.

\section{Microarray hybridization and analysis}

Custom in-house cDNA arrays consisting of 13361 features, representing 7952 unique genes (Unigene Build 152), were spotted on epoxy-coated glass slides (SCHOTT Nexterion, Louisville, KY, USA) using an Omnigrid arrayer (GeneMachines, San Carlos, CA, USA) and Telechem Chipmaker 3 pins in a TeleChem CHP3 printhead head (Telechem International Inc., Sunnyvale, CA, USA) at the DNA Sequencing and Gene Expression Analysis facility at Michigan State University
(East Lansing, MI, USA). Selected clones were obtained from the US Environmental Protection Agency MicroArray Consortium (EPAMAC; Rockett \& Dix 1999), Research Genetics, the National Institute of Aging and Lion Biosciences. Detailed protocols for processing of microarrays are available at http:/ /dbzach.fst.msu.edu.

A $2 \times 2$ factorial hybridization design was used to assess treatment effects (Yang \& Speed 2002) such that each group could be compared with the other (Fig. 1A). Four time-matched samples, of each treatment group, were hybridized to six slides to generate a single replicate of data. Three biological replicates were completed for 2, 4, 12, 24, and $3 \times 24 \mathrm{~h}$ time points for a total of 90 arrays. The Genisphere 900 3DNA Array Detection (Genisphere Inc., Hatfield, PA, USA) indirect incorporation kit was used to generate cDNA samples for hybridization. Briefly, $1 \mu \mathrm{g}$ of RNA was reverse transcribed in the presence of an oligo-tagged primer specifically targeted for Cy3- or Cy5-conjugated dendrimers. The cDNA was resuspended in $58 \mu \mathrm{l}$ of $2 \times$ formamide-based hybridization buffer and hybridized overnight on arrays sealed in a light-shielded, humid chamber submerged in a $42{ }^{\circ} \mathrm{C}$ water bath. Slides were then washed in SSC containing decreasing concentrations of SDS, spin dried, and re-hybridized with a Cy3:Cy5 (1:1) dendrimer mixture in formamidebased buffer to indirectly incorporate dyes at the Cy3and Cy5-dendrimer-tagged cDNA hybridized on the first day. Slides were washed and dried as described earlier, and scanned at $635 \mathrm{~nm}$ (Cy3) and $532 \mathrm{~nm}$ (Cy5) using a Molecular Devices Genepix 4100A scanner (Sunnyvale, CA, USA). Images were examined, features were identified, and intensity values were recorded using GenePix v.5.1 (Molecular Devices).

\section{Microarray quality control, statistical analysis, and gene list filtering}

All arrays were compared with a historical dataset of high-quality arrays. Parameters assessed included background signal intensity, feature signal intensity, feature versus background signal intensity ratios, the number of features with background intensities greater than the feature intensity for each array, and relationships between feature and background signal intensities (Burgoon et al. 2005).

Data were normalized using a semi-parametric approach (Eckel et al. 2005). Model-based $t$ values were calculated comparing all time-matched treated and vehicle samples. Posterior probabilities of activity $(P 1(t)$ value) were then calculated on a per-gene and per-time point basis using an Empirical Bayes analysis (Eckel et al. 2004). Gene lists were filtered to identify genes that demonstrate differential expression between EE and MIX treatment. At each time point, both EE versus $\mathrm{V}(\mathrm{EV})$ and MIX versus $\mathrm{V}$ (MV) lists were 
generated using posterior probability $(P 1(t)>0 \cdot 9999)$ and fold-change cutoff (|fold change| $>1.5$ ) criteria and then compared to identify differential expression between EV and EE versus MIX (EM) where $P 1(t)$ $>0.9999$. All raw and analyzed data were stored in dbZach (http://dbzach.fst.msu.edu), a Minimum Information About Microarray Experiments (MIAME)supportive relational database (Burgoon et al. 2006).

\section{Quantitative real-time-PCR}

Aliquots of RNA isolated from each of the five biological replicates were set aside for SYBR Green quantitative real-time PCR (QRT-PCR) verification. EE-treated, temporal mouse uteri RNA were isolated earlier (Kwekel et al. 2005). An oligo-dT-anchored Superscript II (Invitrogen) reverse transcriptase reaction was carried out on $1 \mu \mathrm{g}$ RNA, in a $20 \mu \mathrm{l}$ reaction, from each biological sample as per the manufacturer's instructions. Samples were diluted fourfold, and $3 \mu$ l were used in a $30 \mu \mathrm{l}$ real-time reaction mix containing $1 \times$ SYBR Green PCR buffer, $3 \mathrm{mM} \mathrm{MgCl}_{2}, 0 \cdot 33 \mathrm{mM}$ dNTPs, $0.5 \mathrm{IU}$ AmpliTaq Gold (Applied Biosystems, Foster City, CA, USA), and $0.15 \mathrm{mM}$ forward and reverse primers. All primers were designed by submitting cDNA microarray clone sequences into Primer3 (http://frodo.wi.mit. edu/primer3) to obtain an amplicon of $\sim 125 \mathrm{bp}$. PCR amplification was conducted in 96-well MicroAmp Optical plates (Applied Biosystems) on an Applied Biosystems PRISM 7000 Sequence Detection System under the following conditions: $10 \mathrm{~min}$ denaturation and enzyme activation at $95^{\circ} \mathrm{C}$, followed by 40 cycles of $95{ }^{\circ} \mathrm{C}$ for $15 \mathrm{~s}$ and $60{ }^{\circ} \mathrm{C}$ for $1 \mathrm{~min}$. After amplification, a $30 \mathrm{~min}$ dissociation protocol was conducted to assess primer specificity and product uniformity. Each plate contained duplicate standards of purified PCR product of known template concentration over eight orders of magnitude to generate a log template concentration standard curve. No template control samples were included on each plate such that experimental samples within 2 s.D. of the NTC are considered below the limits of detection. Plots were visualized and thresholds were determined using ABI Prism 7000 SDS Software (Applied Biosystems). Results were normalized to Rpl7 mRNA levels to control the differences in RNA loading, quality, and cDNA synthesis. Expression differences were assessed using a two-way ANOVA followed by Tukey's HSD post hoc analysis to examine treatment and treatment over time effects (SAS version 9.1). Correlation analyses of QRT-PCR and microarray data were generated using the correlation function of $\mathrm{R} v 2.1 .0$.

\section{LC/MS/MS}

Liver tissue was homogenized with $d_{d d H_{2}} \mathrm{O}$, in a 1:20 dilution, using a handheld Polytron homogenizer (Kinematica, Bohemia, NY, USA). In all, $1 \mathrm{ml} \mathrm{ddH}_{2} \mathrm{O}$, $200 \mu \mathrm{l}$ of $1 \mathrm{M} \mathrm{NaOH}$, and $1 \mathrm{ng}\left[\left[^{15} \mathrm{~N},{ }^{13} \mathrm{C}_{2}\right]\right.$ TAM (Sigma), as an internal standard, were added to $1 \mathrm{ml}$ homogenate. The mixture was extracted in an ether:methanol $(95: 5 \mathrm{v} / \mathrm{v})$ solution and evaporated at $55^{\circ} \mathrm{C}$ under a stream of $\mathrm{N}_{2}$. Residue was resuspended in $200 \mu \mathrm{l}$ acetonitrile:ammonium acetate $(65: 35 \mathrm{v} / \mathrm{v})$ and stored at $-20{ }^{\circ} \mathrm{C}$ in amber sample vials until use. Appropriate standards were also prepared for quantitative inter polation of TAM and 4OH-TAM concentrations.

Extracted samples were analyzed at the MSU Mass Spectrometry Facility (East Lansing, MI, USA). Samples were injected into the LC-20AD (Shimadzu, Columbia, MD, USA) HPLC system with the SIL-5000 Injector (Shimadzu) and separated on an Atlantis dC18 $3 \mathrm{~mm}$ column (Waters Corporation, Milford, MA, USA) using a 60:40 (v/v) methanol:100 $\mathrm{mm}$ ammonium acetate $(\mathrm{pH}=3)$ solution. Electrospray ionization

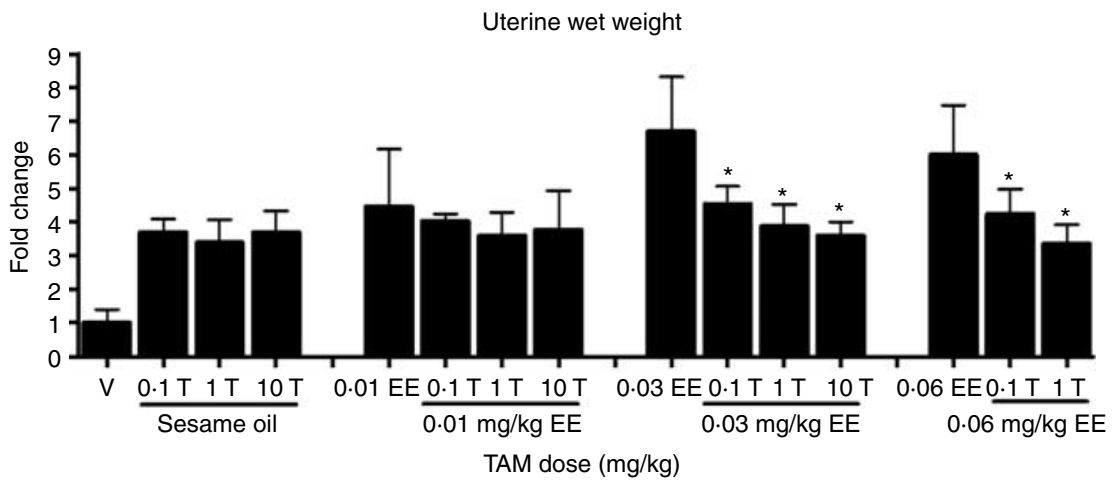

Figure 2 Dose range-finding study: uterotrophic inhibition. Preliminary dose-finding experiments examined effects on uterine wet weight (UWW) at $72 \mathrm{~h}$ after three orally administered daily doses. EE $(0,0.01,0.03$, and $0.06 \mathrm{mg} / \mathrm{kg})$ was cotreated with TAM $(0 \cdot 1,1$, and $10 \mathrm{mg} / \mathrm{kg})$ to determine the optimal doses resulting in inhibition of EE-induced uterotrophy. In all, $0.030 \mathrm{mg} / \mathrm{kg}$ EE plus $1 \mathrm{mg} / \mathrm{kg}$ TAM (1:33 ratio) was selected for further examination. The asterisk $\left(^{*}\right)$ indicates significant $(P<0.05)$ inhibition relative to EE alone. 
mass spectrometry was carried out on a Quattro micro API instrument (Waters Corporation), and data were analyzed using Mass Lynx v4.0 software (Waters Corporation).

\section{Results}

\section{Dose-finding studies}

Preliminary studies were conducted to determine the optimal EE and TAM doses to investigate possible additive, synergistic, and antagonistic uterotrophic tissue and gene expression responses. The oral $\mathrm{ED}_{50}$ for the uterotrophic response in the immature, ovariectomized C57BL/ 6 mice has been previously determined to be $22 \cdot 1$ and $33.7 \mu \mathrm{g} / \mathrm{kg}$ for EE and TAM respectively, and that $100 \mu \mathrm{g} / \mathrm{kg} \mathrm{EE}$ induced a maximal UWW response ( $\sim 10$-fold; Kwekel et al. 2005, Fong et al. 2007). There was also a pronounced temporal delay in TAM-elicited gene expression compared with EE (Fong et al. 2007). Hierarchical clustering illustrated that the $4 \mathrm{~h} \mathrm{EE}$ and $12 \mathrm{~h}$ TAM gene expression profiles were most similar (Fong et al. 2007). In order to accommodate this delay, and to ensure TAM and EE had equivalent access to the ER, a modified treatment regimen was used, which predosed animals with TAM $8 \mathrm{~h}$ before EE (Fig. 1B).

Preliminary dose range-finding studies at $72 \mathrm{~h}$ identified the optimal EE:TAM ratio for the antagonism of EE-induced uterotrophy by TAM. Induction of UWW with 100 and $1000 \mu \mathrm{g} / \mathrm{kg}$ TAM was significantly repressed after cotreatment with 30 and $60 \mu \mathrm{g} / \mathrm{kg} \mathrm{EE}$ (Fig. 2). Consequently, $30 \mu \mathrm{g} / \mathrm{kg}$ EE plus $1000 \mu \mathrm{g} / \mathrm{kg}$ TAM (1:33 ratio) was used to further investigate the additive, synergistic, and antagonistic uterine responses following cotreatment (MIX).

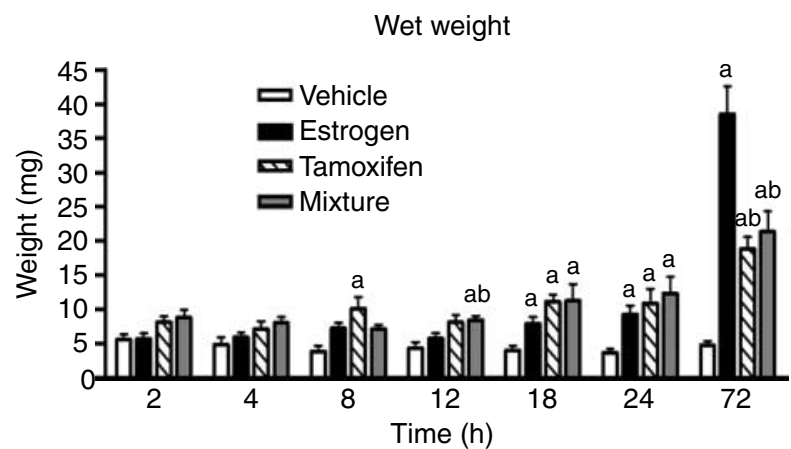

Figure 3 Treatment-induced uterotrophy: uterine wet weight (UWW) was measured at 2, 4, 8, 12, 18, 24, and $72 \mathrm{~h}$ after treatment $(n=5)$; ' $\mathrm{a}$ ' indicates a significant increase in UWW compared with the time-matched vehicle control; 'ab' indicates a significant difference in UWW compared with the time-matched vehicle control and the EE-treated sample.

\section{Treatment effects on uterine weight}

Significant $(P<0 \cdot 05)$ increases in UWW were observed at 18,24 , and $72 \mathrm{~h}$ after treatment with $30 \mu \mathrm{g} / \mathrm{kg} \mathrm{EE}$, and at $8,18,24$, and $72 \mathrm{~h}$ with $1000 \mu \mathrm{g} / \mathrm{kg}$ TAM (Fig. 3). However, TAM only elicited a $4 \cdot 0$-fold increase compared with the $8 \cdot 1$-fold induction by EE at $72 \mathrm{~h}$. Although cotreatment of $30 \mu \mathrm{g} / \mathrm{kg}$ EE plus $1000 \mu \mathrm{g} / \mathrm{kg}$ TAM still increased UWW from 12 to $72 \mathrm{~h}$ compared with vehicle, UWW was inhibited $\sim 50 \%$ at $72 \mathrm{~h}$ compared with EE alone.

\section{Morphometric analysis and histopathology}

Increases in LECH and luminal circumference are uterine hallmarks of estrogenicity (Owens \& Ashby 2002). LECH was significantly induced $3 \cdot 7-, 3 \cdot 5$-, and 3-3-fold by EE, TAM, and MIX treatment respectively compared with time-matched vehicle controls at $72 \mathrm{~h}$ (Fig. 4A). There was no significant difference in LECH between EE and TAM at $72 \mathrm{~h}$, and TAM cotreatment did not antagonize EE-induced LECH. Luminal circumference was induced $3 \cdot 1-$ and $2 \cdot 9$-fold at $24 \mathrm{~h}$,

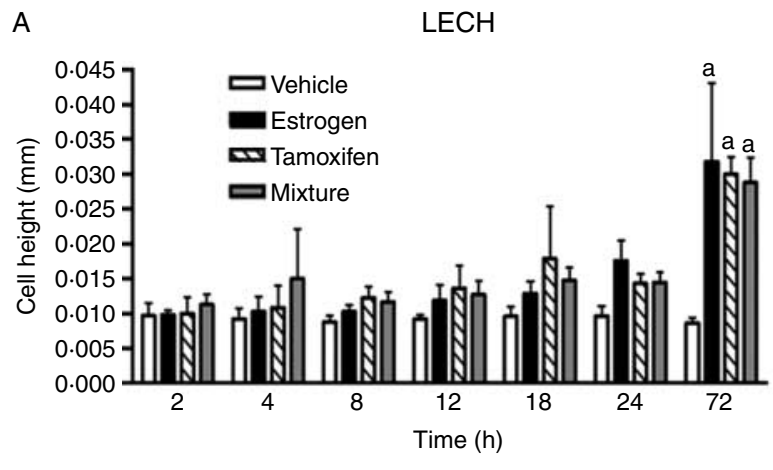

B

Luminal circumference

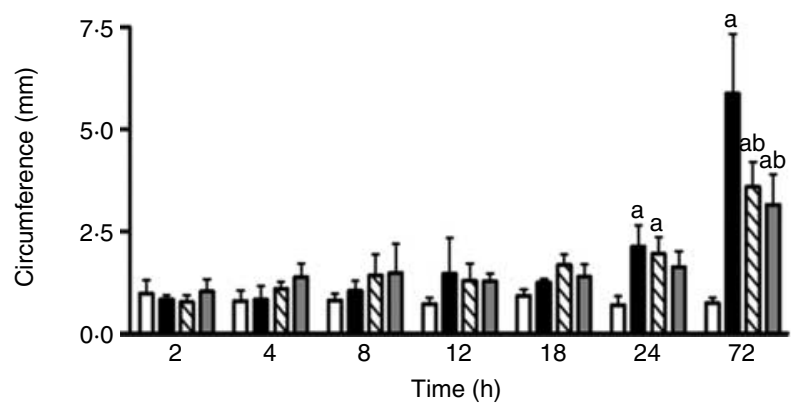

Figure 4 Morphometric changes elicited by EE, TAM, and mixture: morphometric measurements of $(A)$ luminal epithelial cell height $(\mathrm{LECH})$ and $(\mathrm{B})$ luminal circumference were made on all uteri sections; ' $a$ ' indicates a significant increase in LECH or luminal circumference compared with the time-matched vehicle control; 'ab' indicates a significant difference in luminal circumference compared with the time-matched vehicle control and the EE-treated sample. TAM inhibited EE-induced luminal circumference only after three daily treatments. There were no significant differences in $\mathrm{LECH}$ between treatments at any time point examined. 
and $8 \cdot 0$ - and $4 \cdot 9$-fold at $72 \mathrm{~h}$ for EE and TAM respectively (Fig. 4B). MIX repressed luminal circumference by $54 \%$ compared with EE alone at $72 \mathrm{~h}$, but was not significantly different from TAM alone.

\section{Temporal histological changes}

Temporal- and dose-dependent uterine histological changes induced by EE and TAM in the immature, ovariectomized C57BL/ 6 mouse have been described (Kwekel et al. 2005, Fong et al. 2007). The same approach was used to characterize changes elicited by vehicle, EE, TAM, and EE + TAM treatment (Table 1). Mild to moderate stromal edema was observed at $2 \mathrm{~h}$ in the TAM and MIX groups, likely because of early priming. All treatments elicited mild to moderate hypertrophy in stromal nuclei by $4 \mathrm{~h}$, with mild to moderate epithelial hyperplasia in the MIX treatment at $8 \mathrm{~h}$. At $12 \mathrm{~h}, \mathrm{EE}$ induced mild to moderate uterine stromal edema, mild stromal cell hypertrophy, and moderate endometrial hyperplasia, whereas TAM elicited qualitatively similar changes. MIX induced comparable uterine morphology relative to $\mathrm{EE}$ and TAM treatments alone. After $24 \mathrm{~h}, \mathrm{EE}$ and TAM alone elicited marked increases in uterine edema, stromal cell hypertrophy, and endometrial hyperplasia, and were not histologically distinguishable. Comparable changes were also present $24 \mathrm{~h}$ after MIX treatment. The severity of the uterotrophic response continued to $72 \mathrm{~h}$ after EE and TAM alone. In contrast, MIX attenuated the uterine changes induced by EE and TAM alone, as evident in the areas of stromal hypertrophy and endometrial hyperplasia (Fig. 5). Overall, EE, TAM, and MIX elicited similar histological changes. Only at $72 \mathrm{~h}$, there was evidence of a diminished response elicited by MIX when compared with EE and TAM.

\section{LC/MS/MS analysis of liver TAM and 4OH-TAM levels}

Liver samples from the same animals were used as a surrogate because of the limited availability of uterine tissue in order to measure TAM and 4OH-TAM levels by LC/MS/MS (Fig. 6). Extracts from our previous study (Fong et al. 2007) detected TAM in hepatic tissues $2 \mathrm{~h}$ after treatment, which decreased after $4 \mathrm{~h}$ (Fig. 6A), with $4 \mathrm{OH}-\mathrm{TAM}$ reaching a plateau by $4 \mathrm{~h}$ and decreasing after $12 \mathrm{~h}$ (Fig. 6B) as expected. In the current cotreatment study, comparable levels of TAM and 4OH-TAM were detected in hepatic liver extracts

Table 1 Histological evaluations of treated uterine sections. Each treatment group represents a biological replicate of five animals

Treatment
group

\section{Time (h)}

2

4

8

12

18

24

72
Stromal edema

\begin{tabular}{ll}
- & - \\
- & - \\
Mild & - \\
Mild-moderate & None-mild \\
- & - \\
Mild & None-mild \\
Moderate & Mild \\
Mild-moderate & Moderate \\
- & - \\
Mild-moderate & Mild \\
Marked & Mild \\
Marked-severe & Mild \\
- & - \\
Mild-moderate & Moderate \\
Moderate & Mild \\
Moderate & Moderate \\
- & - \\
Mild-moderate & Mild-moderate \\
Moderate-marked & Mild \\
Moderate & Mild \\
- & - \\
Moderate & Moderate \\
Moderate & Moderate \\
Mild-moderate & Mild-moderate \\
- & - \\
Moderate-marked & Marked \\
Moderate & Marked \\
Moderate & Moderate \\
& \\
\hline
\end{tabular}

hypertrophy

Moderate
Epithelial hyperplasia

$\underline{\text { hyperplasia }}$

Myometrial hypertrophy

\begin{tabular}{ll}
- & - \\
- & - \\
- & - \\
- & - \\
- & - \\
- & - \\
- & - \\
- & - \\
- & - \\
- & - \\
Mild-moderate & - \\
Mild-moderate & - \\
- & - \\
Mild-moderate & - \\
Moderate & - \\
Moderate & - \\
- & - \\
Mild-moderate & - \\
Moderate & - \\
Moderate & - \\
- & - \\
Marked & Mild \\
Marked & Mild \\
Moderate-marked & Mild \\
- & - \\
Severe & Mild \\
Severe & Mild \\
Marked-severe & Mild \\
& \\
\hline &
\end{tabular}




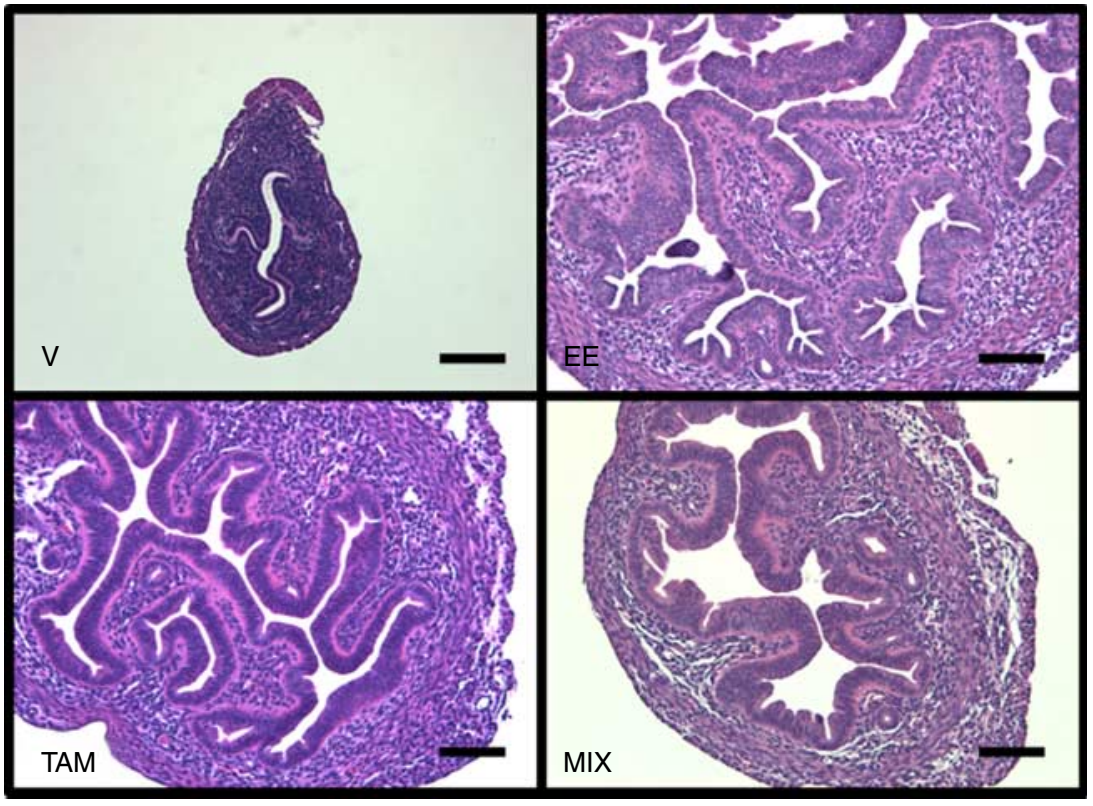

Figure 5 Histological assessment: hematoxylin and eosin staining of uteri treated three times daily with vehicle (V), $30 \mu \mathrm{g} / \mathrm{kg}$ ethynylestradiol (EE), $1000 \mu \mathrm{g} / \mathrm{kg}$ tamoxifen (TAM), and $30 \mu \mathrm{g} / \mathrm{kg}$ ethynylestradiol plus $1000 \mu \mathrm{g} / \mathrm{kg}$ tamoxifen (MIX). All treatments elicited a uterotrophic effect, although MIX attenuated the proliferative effect compared with EE- and TAM-induced responses. Images are representative of five biological replicates; bar represents $30 \mu \mathrm{m}$. Full colour version of this figure available via http://dx.doi.org/10.1677/ JME-09-0158.

(Fig. 6C and D), although there was a shift from the earlier studies because of TAM priming. Approximately $70 \mathrm{ng} / \mathrm{ml} \mathrm{TAM}$ were detected at $2 \mathrm{~h}$ in TAM and MIXtreated liver extracts. Peak levels of $130 \mathrm{ng} / \mathrm{ml}$ were detected at $8 \mathrm{~h}$, which decreased to $50 \mathrm{ng} / \mathrm{ml}$ by $24 \mathrm{~h}$. TAM levels did not significantly differ between TAM and MIX hepatic extracts at any time point. However, 4OH-TAM levels were significantly higher in MIX $(208 \mathrm{ng} / \mathrm{ml})$ compared with TAM $(92 \mathrm{ng} / \mathrm{ml})$ at $2 \mathrm{~h}$, which converged to $100 \mathrm{ng} / \mathrm{ml}$ at $4 \mathrm{~h} ; 4 \mathrm{OH}-\mathrm{TAM}$ levels were not significantly different between TAM and MIX groups at any other time point. It was not possible to determine EE levels because of the low doses administered and the inefficiency of $\mathrm{EE}$ ionization and detection using LC/MS/MS.

\section{Uterine gene expression changes demonstrating mixture effects}

Differentially expressed genes were identified based on their empirical Bayes posterior probability of activity $(P 1(t)$ value) on a per-gene, per-time point basis (Supplementary Table 1, see section on supplementary data given at the end of this article). $P 1(t)$ values approaching 1.0 indicate a greater likelihood of treatment-related differential expression. EE-induced gene expression affected by TAM cotreatment was identified using a two-step process. All genes were first filtered (EE versus $\mathrm{V}$ : $P \mathrm{l}(t) \geq 0.9999$; fold change $\geq 1.5$ ) to identify 2518 EE-elicited gene expression changes for at least one time point. These 2518 genes were then screened for modulation by TAM cotreatment (EE versus MIX: $P 1(t) \geq 0 \cdot 9999$ ) to identify only 290 unique, annotated genes exhibiting gene expression differences comparing MIX to EE, representing potential nonadditive interactions (Table 2).

Gene expression changes were further examined by comparing $\mathrm{EE}$ versus $\mathrm{V}$ and MIX versus $\mathrm{V}$ to classify potential nonadditive interactions as A) EE-induced expression repressed by MIX, B) EE-induced expression augmented by MIX, C) EErepressed expression diminished by MIX, and D) EE-repressed expression further repressed by MIX (Fig. 7 and Table 3). The distribution of gene expression behavior across time shifts from categories $\mathrm{A}, \mathrm{B}$, and $\mathrm{C}$ (2-12 h) to primarily categories B and C ( 24 and $72 \mathrm{~h}$ ). Note that a potential nonadditive interaction may occur at several time points. For example, fos-like antigen 2 (Fosl2) is a category A gene at 2 and $4 \mathrm{~h}$. A gene may also exhibit different nonadditive patterns across time, such as inhibin $\beta$-B $(\operatorname{Inh} b b)$, which is a category A gene at $2 \mathrm{~h}$ but classified as category B at 24 and $72 \mathrm{~h}$. 

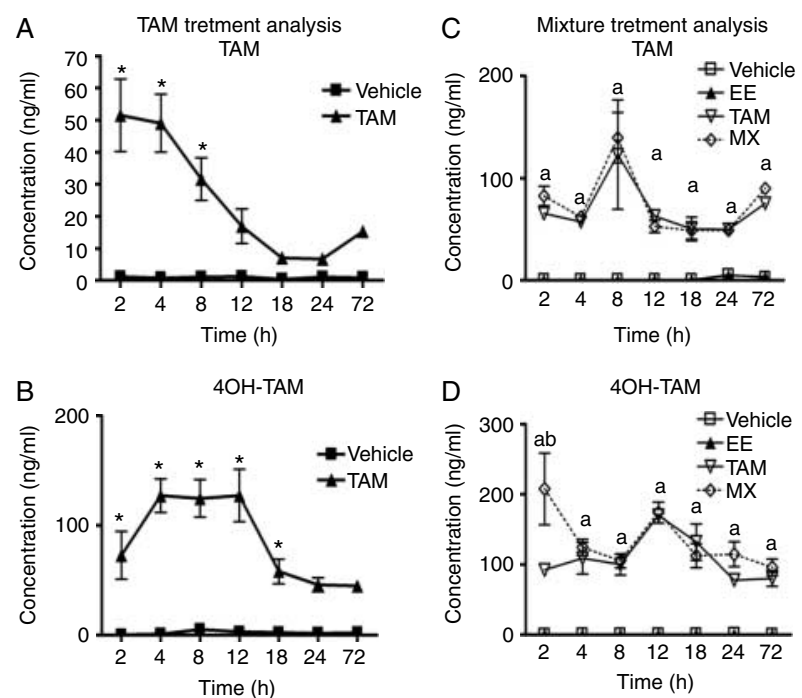

Figure 6 Temporal LC/MS/MS analysis of hepatic TAM and $4 \mathrm{OH}$ TAM levels: hepatic TAM and $4 \mathrm{OH}-\mathrm{TAM}$ were extracted from a previous study (Fong et al. 2007) to determine tissue levels using LC/MS/MS. (A) TAM was detected $\left({ }^{*} P<0.05\right.$ compared with timematched vehicle) at $2 \mathrm{~h}$ after treatment. (B) $4 \mathrm{OH}-\mathrm{TAM}$ levels peaked at $4 \mathrm{~h}\left({ }^{\star} P<0.05\right.$ compared with time-matched vehicle) and plateaued at $12 \mathrm{~h}$ before steadily decreasing over time. TAM and $4 \mathrm{OH}-\mathrm{TAM}$ were also extracted from liver samples from the current study to determine hepatic tissue levels using LC/MS/MS. TAM and $4 \mathrm{OH}-\mathrm{TAM}$ were not significantly different between vehicle and EE treatments. (C) TAM levels in TAM- and MIXtreated samples are significantly different from time-matched vehicle and EE controls ( ${ }^{a} P<0 \cdot 05$ ), but not significantly different between TAM and MIX treatments at any time point. (D) $4 \mathrm{OH}$ TAM levels are significantly different from time-matched vehicle controls and EE-treated animals ( $\left.{ }^{\mathrm{a}} P<0 \cdot 05\right)$. At $2 \mathrm{~h}$, TAM- and MIX-treated animals demonstrate significantly different $4 \mathrm{OH}-\mathrm{TAM}$ levels $\left({ }^{\mathrm{b}} \mathrm{P}<0.05\right)$ but not beyond $4 \mathrm{~h}$ after treatment.

\section{Functional categorization of microarray data}

The majority of EE-elicited differentially expressed genes affected by TAM cotreatment identified at 2 and $4 \mathrm{~h}$ are associated with cell growth and proliferation including oncogenes such as myelocytomatosis oncogene (Myc, category A), Jun oncogene (Jun, category A), and FBJ osteosarcoma oncogene (Fos, category A). Genes involved in the cell cycle, cyclindependent kinase inhibitor 1A (Cdkn1a, category B) and branched chain aminotransferase 1, cytosolic (Bcat1, category B), as well as guanine nucleotidebinding protein-like 3 ( $\mathrm{Gnl} 3$, category B) and activating transcription factor 4 (Atf4, category B), which are associated with proliferation, were also affected by TAM cotreatment. Other affected functional categories included lipid metabolism (peroxisomal trans-2-enoylCoA reductase (Pecr, category $\mathrm{C}$ ) and carnitine palmitoyltransferase 2 (Cpt2, category $\mathrm{C})$ ), immune response (interferon $\gamma$ inducible protein 30 (Ifi30, category $\mathrm{C}$ ) and chemokine (C-X-C motif) ligand 12 (Cxcl12, category $\mathrm{C}$ )), and ion binding and transport (selenoprotein K (Selk, category B) and solute carrier family 23 (nucleobase transporters), member 2 (Slc23a2, category C)) .

Eleven of these genes, representing different categories of MIX-mediated changes from Table 3, were verified by QRT-PCR. Each exhibited a strong correlation between the microarray and QRT-PCR data (Fig. 8). In addition, the more sensitive QRT-PCR assay uncovered an intermediate behavior in the gene expression pattern where MIX induced a significantly greater response than TAM alone but less than EE (Fig. 8).

\section{Discussion}

The uterotrophic assay is a well-established model to study the physiological and morphological effects elicited by estrogenic compounds (Diel et al. 2002). We have used it to examine differential uterine gene expression elicited by EE (Fertuck et al. 2003, Moggs, et al. 2004, Kwekel et al. 2005, Naciff et al. 2007) and, more recently, the partial agonist effects of TAM (Fong et al. 2007). Although TAM inhibits ER-mediated estrogen-induced increases in UWW (Jordan et al. 1978a, Jordan \& Gosden 1983), the effects of cotreatment on gene expression have not been comprehensively examined. In this study, the same model, study design, and analysis methods reported earlier for EE and TAM differential gene expression investigations (Fertuck et al. 2003, Kwekel et al. 2005, Fong et al. 2007) were used to examine the inhibition of EE-induced uterotrophy by TAM cotreatment in order to re-examine several hypotheses regarding the mechanisms involved in the anti-estrogenicity of TAM.

Table 2 MIX-modified, ethynylestradiol (EE)-induced gene list generation. Genes may be active across multiple time points; thus, the sum of each column is greater than total unique genes in each category. Detailed gene information may be found in Supplementary Table 1

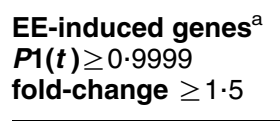

EE-induced genes modified by tamoxifen cotreatment $^{\mathrm{a}} P 1(t)$ $\geq 0.9999$

\begin{tabular}{|c|c|c|}
\hline \multicolumn{3}{|l|}{ Time $(\mathrm{h})$} \\
\hline 2 & 49 & 25 \\
\hline 4 & 336 & 87 \\
\hline 12 & 1946 & 128 \\
\hline 24 & 1534 & 79 \\
\hline 72 & 591 & 48 \\
\hline $\begin{array}{l}\text { Total unique } \\
\text { genes }^{b}\end{array}$ & 2518 & 290 \\
\hline
\end{tabular}
aNumber of unique Entrez gene-annotated genes at indicated time points.
b Number of unique Entrez gene-annotated genes across all time points. 
A

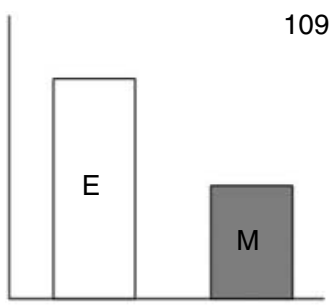

C

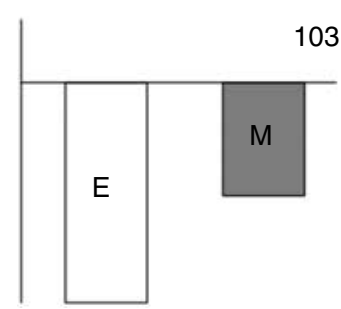

B

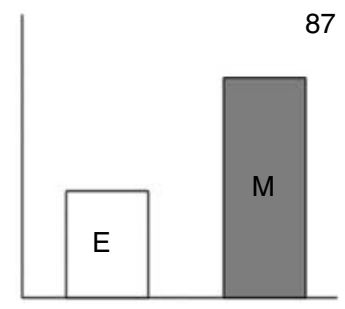

D

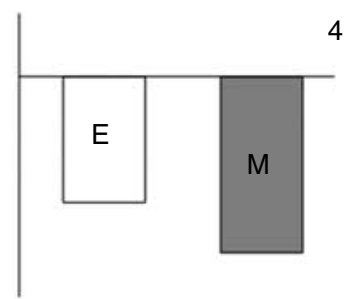

Figure 7 EE-mediated gene expression affected by TAM cotreatment: only 209 out of 2518 EE-elicited gene expression changes $(P 1(t) \geq 0.9999$; fold change $\geq 1.5)$ were affected by TAM cotreatment at doses that significantly inhibited EE-induced uterotrophy. These genes were classified as (A) EE-induced expression repressed by MIX, (B) EE-induced expression augmented by MIX, (C) EE-repressed expression diminished by MIX, and (D) EE-repressed expression that is further repressed by MIX. The numbers within each panel indicate the number of genes exhibiting the pattern. Note that some genes exhibited different TAM cotreatment expression patterns at different time points, and therefore were placed in more than one category.

In this study, TAM inhibited ER-mediated, EE induction of UWW by $\sim 50 \%$ in immature, ovariectomized C57BL6 mice, comparable to other published reports (Jordan et al. 1978a,b, Black \& Goode 1980). Although the model system limited our ability to directly examine TAM levels in the uterus, orally dosed TAM was absorbed and metabolized to 4OH-TAM, consistent with the physiological effects. Histologically, TAM cotreatment inhibited EE induction of luminal circumference but did not antagonize LECH induction, suggesting that the effect is cell-type specific.
Differential gene expression data also indicate that the nonadditive effects of TAM are not global since a majority of EE-elicited responses were not affected by TAM cotreatment. Of the 2518 EE-elicited differential gene responses, only 290 were affected by cotreatment, with 214 being repressed and 76 enhanced, relative to EE alone. Consequently, only a subset of EE-elicited gene expression changes are affected by TAM at doses required to inhibit uterotrophy. In addition, further examination identified 229 differentially expressed genes that showed comparable changes in the EE and MIX groups but were not affected by TAM. Therefore, competition for ER binding (Robertson et al. 1982, Mnif et al. 2007) and downregulation of ER expression (Koibuchi et al. 2000) do not sufficiently explain the gene expression effects resulting in the inhibition of ER-mediated, EE-induced UWW increases.

Examination of the functions of ER-mediated, EE-elicited gene expression affected by TAM is consistent with the inhibition of EE-induced UWW. Several genes associated with growth and proliferation were repressed (category A) by TAM at early time points, including Myc, Jun, and Fos. The proliferation-regulating, uterine-expressed transcription factors, Fosl2 (Bamberger et al. 2001), Ets1, and Ets2 (Kilpatrick et al. 1999), as well as estrogen-responsive proliferationassociated Gtpbp4 (Laping et al. 2001, Wang et al. 2004), uterotrophy-associated Gnl3 (Beekman et al. 2006), and stromal cell differentiation regulator Socs 3 (Dimitriadis et al. 2006) were also repressed and found in category A. Other category A proliferation-related genes including Stx2 (Wang et al. 2006), estrogen-responsive Clu, mouse uterus-expressed Popdc2 (Andree et al. 2000), and Gja1 found in human myometrium (Cluff et al. 2006) were also repressed at later time points. EE-elicited repression of some genes was also attenuated such as Gas1 (category C). Gas 1 is repressed by Myc (Lee et al. 1997), consistent with the repression observed in EE-induced Myc. In addition, the endometrial expression of Cirbp (category $\mathrm{C}$ ), which exhibits an inverse relationship

Table 3 MIX-modified, ethynylestradiol (EE)-induced gene classifications. Detailed gene information may be found in Supplemental Table 1

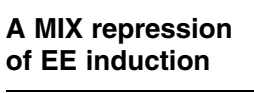
of EE induction

\section{B MIX augmentation} of EE induction

\section{MIX diminution of EE repression}

D MIX augmentation of EE repression

\begin{tabular}{|c|c|c|c|c|}
\hline \multicolumn{5}{|l|}{ Time (h) } \\
\hline 2 & 9 & 15 & 1 & 0 \\
\hline 4 & 58 & 1 & 28 & 0 \\
\hline 12 & 48 & 29 & 50 & 1 \\
\hline 24 & 0 & 45 & 34 & 0 \\
\hline 72 & 5 & 20 & 23 & 0 \\
\hline $\begin{array}{l}\text { Total unique } \\
\text { genes }^{\mathrm{a}}\end{array}$ & 109 & 87 & 106 & 1 \\
\hline
\end{tabular}



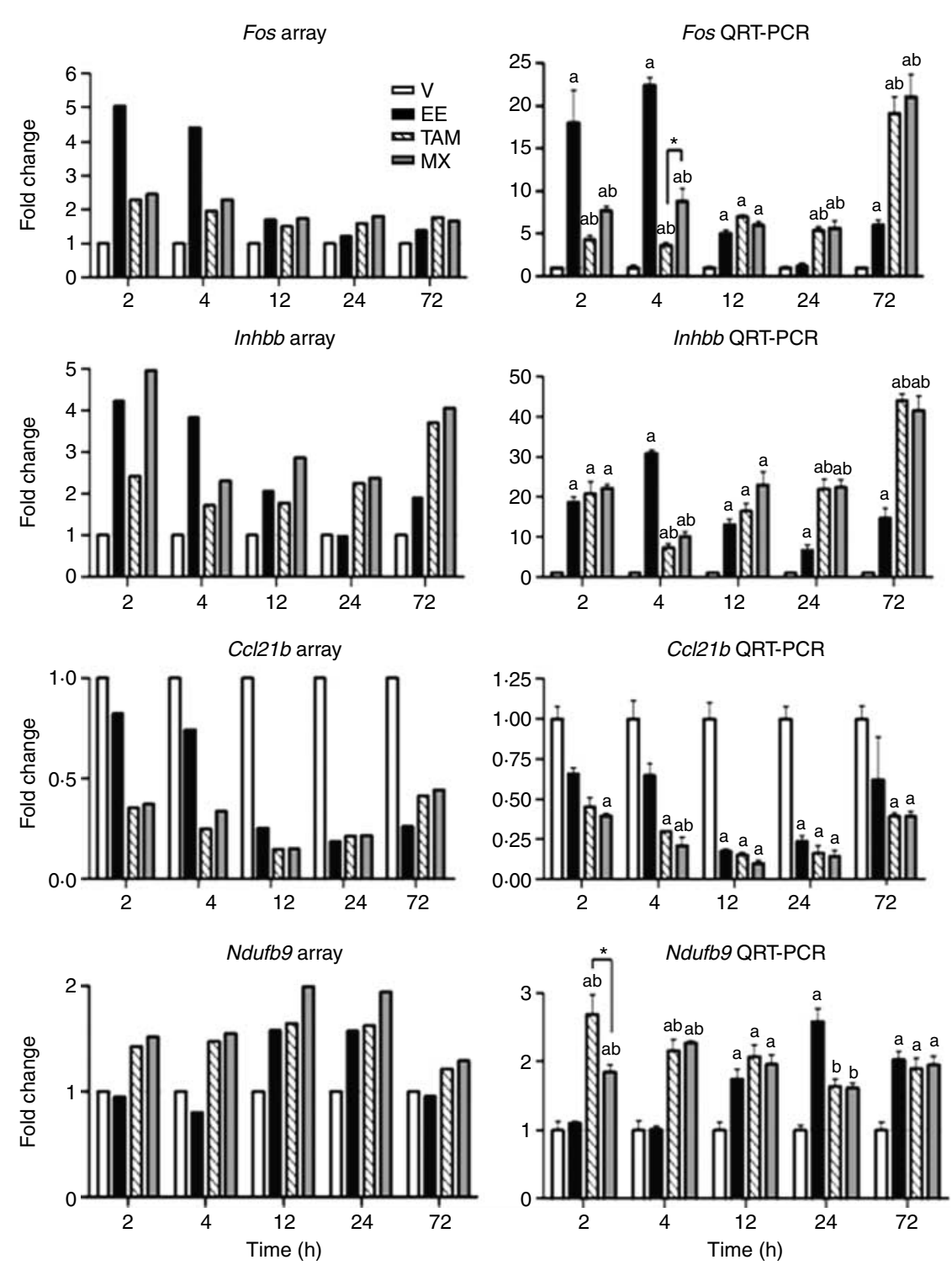

Figure 8 Quantitative real-time PCR verification: microarray results were verified using QRT-PCR with the genes representing various affected pathways and demonstrating different patterns of MIX-modified, EE-mediated changes. Overall, there was good agreement between microarray (left) and QRT-PCR (right) data; 'a' denotes a statistically significant QRT-PCR difference $(P<0.05, n=4)$ because of treatment, 'b' indicates a significant difference from the time-matched EE-treated sample, and * denotes a difference between TAM and MIX-treated samples.

with proliferation (Hamid et al. 2003), was de-repressed by TAM, also consistent with the antagonism of EE-induced UWW.

Furthermore, TAM enhanced the induction or repression of some gene expression changes (categories $\mathrm{B}$ and $\mathrm{D}$ ). Although these responses appear counter intuitive, several are consistent with the inhibition of the EE-induced uterotrophic effect. For example, overexpression of Atf4 (category B) impairs mammary proliferation and development
(Bagheri-Yarmand et al. 2003), and Cdkn1a (category B) is known to promote growth arrest and apoptotic pathways (Qiao et al. 2002). These responses provide further support for a gene expression role in MIX repression of ER-mediated, EE-induced uterine weight. However, there were also late differential responses elicited by EE that were enhanced by TAM cotreatment, and are consistent with proliferation (category B). Crip1 (category $\mathrm{C}$ ), which is upregulated in proliferating mammary luminal epithelial cells (Mackay et al. 2003), 
Cdc2l1 (category C; Wilker et al. 2007), and endometrium-expressed Tgfa (category C; Ejskjaer et al. 2005) all exhibited enhanced differential expression at later time points. This may be an attempt to over compensate for the limited ER-mediated induction of UWW in response to the majority of gene expression changes that were otherwise unaffected under TAM cotreatment or, as is the case with Gas 1 and $M y c$, may be due to changes in the levels of early response genes.

Cytoskeletal reorganization is integral to estrogenmediated restructuring of proliferating tissue (Moggs et al. 2004). Several genes associated with the cytoskeleton including Bicd2 (Hoogenraad et al. 2003), Dctn2 (Uetake et al. 2004), and Mfap5 (Lemaire et al. 2007) were induced by EE and repressed after TAM cotreatment (category A). Although these genes have not been identified to be ER regulated, their differential expression serves to prepare the tissue for proliferation, and therefore, their inhibition is consistent with a compromised uterotrophic response.

Selective ER modulator activity is based on the ability to differentially affect various tissues (Shang \& Brown 2002, Jordan 2007). This study is the first to demonstrate that TAM also elicits selective in vivo gene expression responses within the uterus. Estrogen and 4OH-TAM cotreatment studies in MCF-7 cells have also identified genes that exhibit comparable patterns of antagonism. For example, category A genes Fosl2, Asns (Inoue et al. 2002), and Fos (Frasor et al. 2004), and category C genes Illr1, Tm4sf1, and Ifi30 (Frasor et al. 2004) exhibited similar gene expression behavior in MCF-7 cells and C57BL/6 uterine tissue. Differences in models, study design, microarray platforms, gene representation on the arrays, and data analysis limit comparative analysis to identify additional genes affected by TAM cotreatment in both models. Several factors confound further comparisons between human breast cancer MCF-7 cells and mouse uterine gene expression profiles including differences in ER protein levels (Shang \& Brown 2002), tissue-specific co-regulating factor availability (McDonnell et al. 1995, Webb et al. 2003), and gene-specific thresholds of activation (Geum et al. 1997).

\section{Conclusions}

This study represents the first comprehensive in vivo investigation of the anti-estrogenic effects of TAM on uterine gene expression. Repression of ER-mediated, EE-induced uterotrophy, by TAM cotreatment, did not globally repress all EE-mediated gene expression. In contrast, only a selected subset was affected, which included genes associated with cellular growth and proliferation, consistent with an anti-uterotrophic effect. However, comparative studies in the rat or more sophisticated transgenic approaches are required to conclusively demonstrate the importance of these potential targets in uterine proliferation and growth and as critical TAM targets for the inhibition of ER-mediated, EE-induced increases in UWW.

\section{Supplementary data}

This is linked to the online version of the paper at http://dx.doi.org/ 10.1677/JME-09-0158.

\section{Declaration of interest}

The authors declare that there is no conflict of interest that could be perceived as prejudicing the impartiality of the research reported.

\section{Funding}

Funding for this study was provided by NIHS grant R21 GM75838 to T R Zacharewski as well as fellowships from the MSU Biochemistry and Molecular Biology Department to C J Fong. T R Zacharewski is partially supported by the Michigan Agricultural Experiment Station.

\section{Acknowledgements}

The authors would like to gratefully thank Dr Jeremy Burt for editing the manuscript.

\section{References}

Andree B, Hillemann T, Kessler-Icekson G, Schmitt-John T, Jockusch $\mathrm{H}$, Arnold HH \& Brand T 2000 Isolation and characterization of the novel popeye gene family expressed in skeletal muscle and heart. Developmental Biology 223 371-382. (doi:10.1006/dbio.2000.9751)

Bagheri-Yarmand R, Vadlamudi RK \& Kumar R 2003 Activating transcription factor 4 overexpression inhibits proliferation and differentiation of mammary epithelium resulting in impaired lactation and accelerated involution. Journal Biological Chemistry 278 17421-17429. (doi:10.1074/jbc.M300761200)

Bamberger AM, Milde-Langosch K, Rossing E, Goemann C \& Loning T 2001 Expression pattern of the AP-1 family in endometrial cancer: correlations with cell cycle regulators. Journal of Cancer Research and Clinical Oncology 127 545-550. (doi:10.1007/s004320100255)

Beekman C, Nichane M, De Clercq S, Maetens M, Floss T, Wurst W, Bellefroid E \& Marine JC 2006 Evolutionarily conserved role of nucleostemin: controlling proliferation of stem/progenitor cells during early vertebrate development. Molecular and Cellular Biology 26 9291-9301. (doi:10.1128/MCB.01183-06)

Black LJ \& Goode RL 1980 Uterine bioassay of tamoxifen, trioxifene and a new estrogen antagonist (LY117018) in rats and mice. Life Sciences 26 1453-1458. (doi:10.1016/0024-3205(80)90049-1)

Bolt HM 1979 Metabolism of estrogens - natural and synthetic Pharmacology \& Therapeutics 4 155-181. (doi:10.1016/01637258(79)90018-4)

Brzozowski AM, Pike AC, Dauter Z, Hubbard RE, Bonn T, Engstrom O, Ohman L, Greene GL, Gustafsson JA \& Carlquist M 1997 Molecular basis of agonism and antagonism in the oestrogen receptor. Nature 389 753-758. (doi:10.1038/39645)

Burgoon LD, Eckel-Passow JE, Gennings C, Boverhof DR, Burt JW, Fong CJ \& Zacharewski T 2005 Protocols for the assurance of microarray data quality and process control. Nucleic Acids Research 33 e172. (doi:10.1093/nar/gni167) 
Burgoon LD, Boutros PC, Dere E \& Zacharewski TR 2006 dbZach: a MIAME-compliant toxicogenomic supportive relational database. Toxicological Sciences 90 558-568. (doi:10.1093/toxsci/kfj097)

Castellano-Diaz E, Gonzalez-Quijano MI, Liminana JM \& Diaz-Chico BN 1989 Tamoxifen decreases the estradiol induced progesterone receptors by interfering with nuclear estrogen receptor accumulation. Journal of Steroid Biochemistry 33 133-139. (doi:10.1016/00224731(89)90368-3)

Cluff AH, Bystrom B, Klimaviciute A, Dahlqvist C, Cebers G, Malmstrom A \& Ekman-Ordeberg G 2006 Prolonged labour associated with lower expression of syndecan 3 and connexin 43 in human uterine tissue. Reproductive Biology and Endocrinology 424. (doi:10.1186/1477-7827-4-24)

Das D, Peterson RC \& Scovell WM 2004 High mobility group B proteins facilitate strong estrogen receptor binding to classical and half-site estrogen response elements and relax binding selectivity. Molecular Endocrinology 18 2616-2632. (doi:10.1210/me.2004-0125)

Diel P, Schmidt S \& Vollmer G 2002 In vivo test systems for the quantitative and qualitative analysis of the biological activity of phytoestrogens. Journal of Chromatography. B, Analytical Technologies in the Biomedical and Life Sciences 777 191-202. (doi:10.1016/S15700232(02)00494-4)

Dimitriadis E, Stoikos C, Tan YL \& Salamonsen LA 2006 Interleukin 11 signaling components signal transducer and activator of transcription 3 (STAT3) and suppressor of cytokine signaling 3 (SOCS3) regulate human endometrial stromal cell differentiation. Endocrinology 147 3809-3817. (doi:10.1210/en.2006-0264)

Eckel JE, Gennings C, Chinchilli VM, Burgoon LD \& Zacharewski TR 2004 Empirical Bayes gene screening tool for time-course or doseresponse microarray data. Journal of Biopharmaceutical Statistics $\mathbf{1 4}$ 647-670. (doi:10.1081/BIP-200025656)

Eckel JE, Gennings C, Therneau TM, Burgoon LD, Boverhof DR \& Zacharewski TR 2005 Normalization of two-channel microarray experiments: a semiparametric approach. Bioinformatics 21 1078-1083. (doi:10.1093/bioinformatics/bti105)

Edwards DP 2000 The role of coactivators and corepressors in the biology and mechanism of action of steroid hormone receptors. Journal of Mammary Gland Biology and Neoplasia 5 307-324. (doi:10. 1023/A:1009503029176)

Ejskjaer K, Sorensen BS, Poulsen SS, Mogensen O, Forman A \& Nexo E 2005 Expression of the epidermal growth factor system in human endometrium during the menstrual cycle. Molecular Human Reproduction 11 543-551. (doi:10.1093/molehr/gah207)

Fertuck KC, Eckel JE, Gennings C \& Zacharewski TR 2003 Identification of temporal patterns of gene expression in the uteri of immature, ovariectomized mice following exposure to ethynylestradiol. Physiological Genomics 15 127-141. (doi:10.1152/physiolgenomics.00058.2003)

Fong CJ, Burgoon LD, Williams KJ, Forgacs AL \& Zacharewski TR 2007 Comparative temporal and dose-dependent morphological and transcriptional uterine effects elicited by tamoxifen and ethynylestradiol in immature, ovariectomized mice. BMC Genomics 8151. (doi:10.1186/1471-2164-8-151)

Frasor J, Stossi F, Danes JM, Komm B, Lyttle CR \& Katzenellenbogen BS 2004 Selective estrogen receptor modulators: discrimination of agonistic versus antagonistic activities by gene expression profiling in breast cancer cells. Cancer Research 64 1522-1533. (doi:10.1158/ 0008-5472.CAN-03-3326)

Geum D, Sun W, Paik SK, Lee CC \& Kim K 1997 Estrogen-induced cyclin D1 and D3 gene expressions during mouse uterine cell proliferation in vivo: differential induction mechanism of cyclin D1 and D3. Molecular Reproduction and Development 46 450-458. (doi:10.1002/ (SICI) 1098-2795(199704) 46:4 < 450::AID-MRD2>3. $0 . \mathrm{CO} ; 2-\mathrm{N})$

Hamid AA, Mandai M, Fujita J, Nanbu K, Kariya M, Kusakari T, Fukuhara K \& Fujii S 2003 Expression of cold-inducible RNAbinding protein in the normal endometrium, endometrial hyperplasia, and endometrial carcinoma. International Journal of Gynecological Pathology 22 240-247. (doi:10.1097/01.PGP. 0000070851.25718.EC)

Hodges LC, Cook JD, Lobenhofer EK, Li L, Bennett L, Bushel PR, Aldaz CM, Afshari CA \& Walker CL 2003 Tamoxifen functions as a molecular agonist inducing cell cycle-associated genes in breast cancer cells. Molecular Cancer Research 1 300-311.

Hoogenraad CC, Wulf P, Schiefermeier N, Stepanova T, Galjart N, Small JV, Grosveld F, de Zeeuw CI \& Akhmanova A 2003 Bicaudal D induces selective dynein-mediated microtubule minus end-directed transport. EMBO Journal 22 6004-6015. (doi:10.1093/emboj/ cdg592)

Houssami N, Cuzick J \& Dixon JM 2006 The prevention, detection, and management of breast cancer. Medical Journal of Australia 184 230-234.

Inoue A, Yoshida N, Omoto Y, Oguchi S, Yamori T, Kiyama R \& Hayashi S 2002 Development of cDNA microarray for expression profiling of estrogen-responsive genes. Journal of Molecular Endocrinology 29 175-192. (doi:10.1677/jme.0.0290175)

Jordan VC 1993 Fourteenth Gaddum Memorial Lecture. A current view of tamoxifen for the treatment and prevention of breast cancer. British Journal of Pharmacology 110 507-517.

Jordan VC 2007 Chemoprevention of breast cancer with selective oestrogen-receptor modulators. Nature Reviews. Cancer 7 46-53. (doi:10.1038/nrc2048)

Jordan VC \& Gosden B 1983 Inhibition of the uterotropic activity of estrogens and antiestrogens by the short acting antiestrogen LY117018. Endocrinology 113 463-468. (doi:10.1210/endo113-2-463)

Jordan VC, Dix CJ, Naylor KE, Prestwich G \& Rowsby L 1978a Nonsteroidal antiestrogens: their biological effects and potential mechanisms of action. Journal of Toxicology and Environmental Health 4 363-390. (doi:10.1080/15287397809529666)

Jordan VC, Rowsby L, Dix CJ \& Prestwich G 1978b Dose-related effects of non-steroidal antioestrogens nad oestrogens on the measurement of cytoplasmic oestrogen receptors in the rat and mouse uterus. Journal of Endocrinology 78 71-81. (doi:10.1677/joe.0. 0780071)

Kedar RP, Bourne TH, Powles TJ, Collins WP, Ashley SE, Cosgrove DO \& Campbell S 1994 Effects of tamoxifen on uterus and ovaries of postmenopausal women in a randomised breast cancer prevention trial. Lancet 343 1318-1321. (doi:10.1016/S0140-6736(94)92466-X)

Kilpatrick LM, Kola I \& Salamonsen LA 1999 Transcription factors Ets1, Ets2, and Elf1 exhibit differential localization in human endometrium across the menstrual cycle and alternate isoforms in cultured endometrial cells. Biology of Reproduction 61 120-126. (doi:10.1095/biolreprod61.1.120)

Kirkland JL, Murthy L \& Stancel GM 1993 Tamoxifen stimulates expression of the c-fos proto-oncogene in rodent uterus. Molecular Pharmacology 43 709-714.

Koibuchi Y, Iino Y, Uchida T, Andoh T, Horii Y, Nagasawa M, Horiguchi J, Maemura M, Takei H, Yokoe T et al. 2000 Regulation of estrogen receptor and epidermal growth factor receptor by tamoxifen under high and low estrogen environments in MCF-7 cells grown in athymic mice. Oncology Reports 7 135-140.

Kwekel JC, Burgoon LD, Burt JW, Harkema JR \& Zacharewski TR 2005 A cross-species analysis of the rodent uterotrophic program: elucidation of conserved responses and targets of estrogen signaling. Physiological Genomics 23 327-342. (doi:10.1152/physiolgenomics.00175.2005)

Kwekel JC, Forgacs AL, Burgoon LD, Williams KJ \& Zacharewski TR 2009 Tamoxifen-elicited uterotrophy: cross-species and cross-ligand analysis of the gene expression program. BMC Medical Genomics 2 19. (doi:10.1186/1755-8794-2-19)

Laping NJ, Olson BA \& Zhu Y 2001 Identification of a novel nuclear guanosine triphosphate-binding protein differentially expressed in renal disease. Journal of the American Society of Nephrology 12 883-890. 
Lee TC, Li L, Philipson L \& Ziff EB 1997 Myc represses transcription of the growth arrest gene gas1. PNAS 94 12886-12891. (doi:10.1073/ pnas.94.24.12886)

Lemaire R, Bayle J, Mecham RP \& Lafyatis R 2007 Microfibrilassociated MAGP-2 stimulates elastic fiber assembly. Journal of Biological Chemistry 282 800-808. (doi:10.1074/jbc.M609692200)

Lewis JS \& Jordan VC 2005 Selective estrogen receptor modulators (SERMs): mechanisms of anticarcinogenesis and drug resistance. Mutation Research 591 247-263. (doi:10.1016/j.mrfmmm.2005.02.028)

Mackay A, Jones C, Dexter T, Silva RL, Bulmer K, Jones A, Simpson P, Harris RA, Jat PS, Neville AM et al. 2003 cDNA microarray analysis of genes associated with ERBB2 (HER2/neu) overexpression in human mammary luminal epithelial cells. Oncogene 22 2680-2688. (doi:10.1038/sj.onc.1206349)

Massarweh S, Osborne CK, Creighton CJ, Qin L, Tsimelzon A, Huang S, Weiss H, Rimawi M \& Schiff R 2008 Tamoxifen resistance in breast tumors is driven by growth factor receptor signaling with repression of classic estrogen receptor genomic function. Cancer Research 68 826-833. (doi:10.1158/0008-5472.CAN-07-2707)

McDonnell DP, Clemm DL, Hermann T, Goldman ME \& Pike JW 1995 Analysis of estrogen receptor function in vitro reveals three distinct classes of antiestrogens. Molecular Endocrinology 9 659-669. (doi:10. $1210 /$ me.9.6.659)

McInerney EM \& Katzenellenbogen BS 1996 Different regions in activation function-1 of the human estrogen receptor required for antiestrogen- and estradiol-dependent transcription activation. Journal of Biological Chemistry 271 24172-24178. (doi:10.1074/jbc. 271.39.24172)

Mnif W, Pascussi JM, Pillon A, Escande A, Bartegi A, Nicolas JC, Cavailles V, Duchesne MJ \& Balaguer P 2007 Estrogens and antiestrogens activate hPXR. Toxicology Letters 170 19-29. (doi:10. 1016/j.toxlet.2006.11.016)

Moggs JG, Tinwell H, Spurway T, Chang HS, Pate I, Lim FL, Moore DJ, Soames A, Stuckey R, Currie R et al. 2004 Phenotypic anchoring of gene expression changes during estrogen-induced uterine growth. Environmental Health Perspectives 112 1589-1606. (doi:10. $1289 /$ txg.7345)

Naciff JM, Overmann GJ, Torontali SM, Carr GJ, Khambatta ZS, Tiesman JP, Richardson BD \& Daston GP 2007 Uterine temporal response to acute exposure to 17\{alpha\}-ethinyl estradiol in the immature rat. Toxicological Sciences 97 467-490. (doi:10.1093/toxsci/ $\mathrm{kfm} 046$ )

Owens JW \& Ashby J 2002 Critical review and evaluation of the uterotrophic bioassay for the identification of possible estrogen agonists and antagonists: in support of the validation of the OECD uterotrophic protocols for the laboratory rodent. Organisation for Economic Co-operation and Development. Critical Reviews in Toxicology 32 445-520. (doi:10.1080/20024091064291)

Parrott E, Butterworth M, Green A, White IN \& Greaves P 2001 Adenomyosis - a result of disordered stromal differentiation. American Journal of Pathology 159 623-630.

Pike AC, Brzozowski AM, Hubbard RE, Bonn T, Thorsell AG, Engstrom O, Ljunggren J, Gustafsson JA \& Carlquist M 1999 Structure of the ligand-binding domain of oestrogen receptor beta in the presence of a partial agonist and a full antagonist. $E M B O$ Journal 18 4608-4618. (doi:10.1093/emboj/18.17.4608)

Pole JC, Gold LI, Orton T, Huby R \& Carmichael PL 2005 Gene expression changes induced by estrogen and selective estrogen receptor modulators in primary-cultured human endometrial cells: signals that distinguish the human carcinogen tamoxifen. Toxicology 206 91-109. (doi:10.1016/j.tox.2004.07.005)
Qiao L, McKinstry R, Gupta S, Gilfor D, Windle JJ, Hylemon PB, Grant S, Fisher PB \& Dent P 2002 Cyclin kinase inhibitor p21 potentiates bile acid-induced apoptosis in hepatocytes that is dependent on p53. Hepatology 36 39-48. (doi:10.1053/jhep.2002.33899)

Reel JR, Lamb IJ \& Neal BH 1996 Survey and assessment of mammalian estrogen biological assays for hazard characterization. Fundamental and Applied Toxicology 34 288-305. (doi:10.1006/faat. 1996.0198)

Robertson DW, Katzenellenbogen JA, Long DJ, Rorke EA \& Katzenellenbogen BS 1982 Tamoxifen antiestrogens. A comparison of the activity, pharmacokinetics, and metabolic activation of the cis and trans isomers of tamoxifen. Journal of Steroid Biochemistry 16 1-13. (doi:10.1016/0022-4731(82)90137-6)

Rockett JC \& Dix DJ 1999 Application of DNA arrays to toxicology. Environmental Health Perspectives 107 681-685. (doi:10.2307/ 3434462)

Shang Y \& Brown M 2002 Molecular determinants for the tissue specificity of SERMs. Science 295 2465-2468. (doi:10.1126/science. 1068537)

Shiau AK, Barstad D, Loria PM, Cheng L, Kushner PJ, Agard DA \& Greene GL 1998 The structural basis of estrogen receptor/coactivator recognition and the antagonism of this interaction by tamoxifen. Cell 95 927-937. (doi:10.1016/S0092-8674(00)81717-1)

Sourla A, Luo S, Labrie C, Belanger A \& Labrie F 1997 Morphological changes induced by 6 -month treatment of intact and ovariectomized mice with tamoxifen and the pure antiestrogen EM-800. Endocrinology 138 5605-5617. (doi:10.1210/en.138.12.5605)

Uetake Y, Terada Y, Matuliene J \& Kuriyama R 2004 Interaction of Cep135 with a p50 dynactin subunit in mammalian centrosomes. Cell Motility and the Cytoskeleton 58 53-66. (doi:10.1002/cm.10175)

Vosse M, Renard F, Coibion M, Neven P, Nogaret JM \& Hertens D 2002 Endometrial disorders in 406 breast cancer patients on tamoxifen: the case for less intensive monitoring. European Journal of Obstetrics, Gynecology, and Reproductive Biology 101 58-63. (doi:10.1016/S03012115(01)00516-4)

Wang DY, McKague B, Liss SN \& Edwards EA 2004 Gene expression profiles for detecting and distinguishing potential endocrinedisrupting compounds in environmental samples. Environmental Science and Technology 38 6396-6406. (doi:10.1021/es049235r)

Wang Y, Wang L, Iordanov H, Swietlicki EA, Zheng Q, Jiang S, Tang Y, Levin MS \& Rubin DC 2006 Epimorphin $(-/-)$ mice have increased intestinal growth, decreased susceptibility to dextran sodium sulfate colitis, and impaired spermatogenesis. Journal of Clinical Investigation 116 1535-1546. (doi:10.1172/JCI25442)

Weatherman RV, Chang CY, Clegg NJ, Carroll DC, Day RN, Baxter JD, McDonnell DP, Scanlan TS \& Schaufele F 2002 Ligand-selective interactions of ER detected in living cells by fluorescence resonance energy transfer. Molecular Endocrinology 16 487-496. (doi:10.1210/ me.16.3.487)

Webb P, Nguyen P \& Kushner PJ 2003 Differential SERM effects on corepressor binding dictate ERalpha activity in vivo. Journal of Biological Chemistry 278 6912-6920. (doi:10.1074/jbc.M208501200)

Wilker EW, van Vugt MA, Artim SA, Huang PH, Petersen CP, Reinhardt HC, Feng Y, Sharp PA, Sonenberg N, White FM et al. 2007 14-33sigma controls mitotic translation to facilitate cytokinesis. Nature 446 329-332. (doi:10.1038/nature05584)

Yang YH \& Speed T 2002 Design issues for cDNA microarray experiments. Nature Reviews. Genetics 3 579-588. (doi:10.1038/nrg863)

Received in final form 28 June 2010

Accepted 7 July 2010

Made available online as an Accepted Preprint 13 July 2010 